\title{
Türkiye Ekmeklik Buğday Genotiplerinde Tescil Yılı ile Bitki Boyu, Çim Kını Uzunluğu ve Tane Verimi Arasındaki İlișkiler
}

\author{
*Sinan BAYRAM¹, Ali ÖZTÜRK², Murat AYDIN² \\ ${ }^{1}$ GAP Uluslararası Tarımsal Araștırma ve Eğitim Merkezi, Diyarbakır \\ ${ }^{2}$ Atatürk Üniversitesi, Ziraat Fakültesi, Tarla Bitkileri Bölümü, Erzurum \\ *Sorumlu yazar e-posta (Corresponding author e-mail): sinan.bayram@tarim.gov.tr
}

\section{Öz}

Bu araștırma, 2009-2011 döneminde Atatürk Üniversitesi Ziraat Fakültesi deneme alanı ve Tarla Bitkileri Bölümü bitki büyütme odalarında yürütülmüș, bitki materyali olarak 64 ekmeklik buğday genotipi kullanılmıștır. Genotipler tescil yıllarına göre gruplandırımıș (yerel genotipler, 1929-1968, 1970-1979, 19881994, 1995-1999 ve 2000-2006 dönemleri); dört farklı test ortamındaki çim kını uzunlukları ile bitki boyu ve tane verimi arasındaki ilișkiler incelenmiștir. Tescil yılı ile bitki boyu, toprak-karanlık çim kını uzunluğu, toprak-aydınlık çim kını uzunluğu ve kâğıt-karanlık çim kını uzunluğu arasında olumsuz ve önemli, tescil yılı ile tane verimi arasında ise olumlu ve önemli ilișki olduğu belirlenmiștir. Grupların incelenen karakterler ile olan ilișkileri biplot analiz yöntemi ile incelenmiș, biplot grafiğinde yerel genotiplerin bitki boyu ve çim kını uzunluklarına çok yakın, tane verimine ise uzak olduğu, tescil yılı arttıkça grupların bitki boyu ve çim kını uzunluğundan uzaklașıp tane verimine yaklaștığı görülmüștür. 2000-2006 döneminde tescil edilen çeșitlerin olușturduğu VI. grubun çim kını uzunluğu ve bitki boyuna en uzak, tane verimine ise en yakın olduğu belirlenmiștir. Islah çalıșmalarının Türk ekmeklik buğday çeșitlerinde bitki boyu ile birlikte çim kınını da kısalttığı, tane verimini ise arttırdığı belirlenmiștir.

Anahtar kelimeler: Ekmeklik buğday, tescil yılı, bitki boyu, çim kını uzunluğu, verim

\section{Relationships between Plant Height, Coleoptile Length, Grain Yield with Registration Year in Bread Wheat Genotypes of Turkey}

\section{Abstract}

This research was carried out at plant growth chambers of Field Crops Department, at experimental area the Faculty of Agriculture at Atatürk University, between 2009 and 2011. A total of 64 bread wheat genotypes were used as plant material in the study. Genotypes were grouped according to registration years (local genotypes, 1929-1968, 1970-1979, 1988-1994, 1995-1999 and 2000-2006 periods); the relationships between coleoptile length in four different test environments and plant height and grain yield were investigated. There is a positive and significant relationship between the registration year and the grain yield. It was determined that there is a negative and significant relationship between registration year and plant height, soil-dark coleoptile length, soil-light coleoptile length, paper-dark coleoptile length. The relationship between the groups and the features were examined by biplot analysis method. In the biplot graphic created with the average values of groups, it was observed that local genotypes were very close to plant length and coleoptile length and were far away to grain yield. As the registration year increases, the groups moved away from the plant height and coleoptile lengths and approached grain yield. It was determined that the 6th group formed by cultivars registered in 2000-2006 period was furthest to coleoptile length and plant height, and closest to grain yield. It was determined that in Turkish bread wheat cultivars breeding shortened the coleoptile length along with the plant height, and increase grain yield.

Keywords: Bread wheat, registration year, plant height, coleoptile length, grain yield 


\section{Giriș}

A nadolu'da binlerce yıldır en önemli besin kaynağı olan buğday, ülkemizde 7.671.945 ha ekim alanına ve 20.600.000 ton üretime sahiptir (Anonim, 2017). Buğdayda verim ve kaliteyi arttırmayı ve bunları sınırlayan kuraklık, düșük veya yüksek sıcaklık, kıș zararı, yatma, mikro element eksikliği, hastalık ve zararlılar gibi etmenlere karșı dayanıklı çeșitler geliștirmeyi hedefleyen ıslah çalıșmaları ile, yeni çeșitler geliștirilmektedir. Türkiye'de buğday ıslah çalıșmaları 1925 yılında Eskișehir Tohum Islah İstasyonu'nda bașlamıș, 1960'lı yıllarda hız kazanmıș ve 2016 yılı milli çeșit listesine göre tescilli ekmeklik buğday çeșidi sayısı 212'ye ulașmıștır. Yeșil Devrim ile, kısa boylu buğday genotiplerinin geliștirilmesi tane veriminde önemli artıșlar sağlamıștır (Tang ve ark. 2009). Geleneksel ıslah yöntemleri sonucu yeni çeșitlerde potansiyel verim artmıș ve genetik ilerleme sağlanmıștır. Tane verimindeki artıș yarı bodur genotiplerin kullanımı ile ilișkili olmuș, bu durum hasat indeksindeki artıșla açıklanmıștır (Bodega ve Andrade 1996). İngiltere'de 1948-1990 döneminde buğday verimi yılda $110 \mathrm{~kg} \mathrm{ha}^{-1}$ artıș göstermiș, kısa boylu çeșitlerin ıslahı ile daha yüksek verimler elde edilmiștir (Austin 1999). Tahıllarda bitki boyu arttıkça çim kını uzunluğu da artmaktadır (Rebetzke ve ark. 2001). Buğdayda bitki boyu ile çim kını uzunluğu arasında olumlu ilișki, bitki boyu kısaldıkça çim kını uzunluğunun da azaldığını göstermektedir. Çim kını uzunluğu arttıkça bitki tane dolum döneminde intiyaç duyduğu suyu toprağın daha derin kısımlarından sağlayabilmekte, daha uzun süre yeșil kalıp daha fazla fotosentez yapabilmektedir (Tang ve ark. 2009). Modern çeșitlerde bitki boyunun kısa, çim kınının ise uzun olması aranan bir özelliktir (Rebetzke ve ark. 2012). Ancak, modern buğday çeșitlerinde genç yaprak ve sap dokusu hücrelerinin uzamasındaki azalmalar, bitki boyu ile birlikte çim kını uzunluğunda da azalmalarla sonuçlanmıștır (Richards 1992). Bitki boyu ile çim kını uzunluğu arasındaki ilișkileri araștıran Rebetzke ve ark. (1999), iki karakter yönünden de buğdayda önemli genetik varyasyonun bulunduğunu, çim kını uzunluğundaki varyasyonun bitki boyu ile ilișkisinin zayıf ve çim kını uzunluğunun kalıım derecesinin yüksek olduğunu, elverișsiz koșullarda fide tesisi ve fide gücünü arttırabilmek için bitki boyu kısa fakat çim kını uzun genotiplerin geliștirilebileceğini bildirmișlerdir.

Bu araștırmada, Türkiye ekmeklik buğday genotiplerinde tescil yılı ile bitki boyu, çim kını uzunluğu ve tane verimi arasındaki ilișkilerin belirlenmesi amaçlanmıștır.

\section{Materyal ve Yöntem}

Araștırmada, 44'ü 2007 yılı milli çeșit listesinde yer alan çeșitlerden, 20'si ise 2007 yılı milli çeșit listesinde yer almayan eski çeșitler ve yerel genotiplerden olușan toplam 64 ekmeklik buğday genotipi yer almıștır. Gübre kaynağı olarak amonyum sülfat ve triple süperfosfat, toprak ortamında çim kını uzunluğu denemelerinde ise $\% 0.98 \mathrm{~N}, \% 0.02 \mathrm{P}, \% 0.09$ $\mathrm{K}, \% 0.84 \mathrm{Ca}, \% 0.28 \mathrm{Mg}, 2820 \mathrm{ppm} \mathrm{Fe}, 41 \mathrm{ppm}$ $\mathrm{Mn}, 9 \mathrm{ppm} \mathrm{Zn}, \% 36.6$ organik madde, \%49 nem içeren ve pH'। 6.7 olan 'T. T. Makro, TorfFide Yetiștirme Toprağı" kullanılmıștır.

Tarla denemesi topraklarının tekstür sınıfının killi-tın, organik madde oranlarının az, nötr reaksiyonlu, fosfor yönünden orta, potasyum yönünden ise çok zengin (Ergene 1993) olduğu belirlenmiștir. Erzurum iline ait toplam yağıș miktarı uzun yıllar ortalaması 395.2 mm'dir. Araștırmanın yürütüldüğü 20092010 ve 2010-2011 ürün yıllarına ait toplam yağıș miktarları ise sırası ile 533.2 ve $513.3 \mathrm{~mm}$ olmuș ve uzun yıllar ortalamasına göre önemli miktarda fazla yağıș düșmüștür. Erzurum'da yıllık ortalama sıcaklık $5.0^{\circ} \mathrm{C}$ 'dir. Araștırmanın yürütüldüğü ürün yıllarında ortalama sıcaklık ise sırası ile 7.5 ve $6.4^{\circ} \mathrm{C}$ olmuștur.

Atatürk Üniversitesi Ziraat Fakültesi 4 numaralı deneme alanında, tesadüf blokları deneme desenine göre dört tekrarlı olarak yürütülmüștür. Genotipler her blokta șansa bağlı olarak dağıtılmıș, ekim ișlemleri toprak hazırlığı yapıımıș nadas araziye 7 Eylül 2009 ve 16 Eylül 2010 tarihlerinde, elle ve her genotip bir sıra olacak șekilde yapılmıștır. Bloklar tava haline getirildikten sonra, $6 \mathrm{~kg} \mathrm{da}^{-1} \mathrm{~N}$ ve $5 \mathrm{~kg}$ da- $1 \mathrm{P}_{2} \mathrm{O}_{5}$ olacak șekilde (fosforun tamamı ve azotun yarısı ekimle birlikte, azotun diğer yarısı ise sapa kalkma bașlangıcında) gübrelenmiștir. Daha sonra $1.0 \mathrm{~m}$ uzunluğunda, $3-5 \mathrm{~cm}$ 
derinliğinde ve $20 \mathrm{~cm}$ aralıkla açılan markör sıralarına, $\mathrm{m}^{2}$ ye 475 canlı tohum sıklı̆ı̆ında ekim yapılmıștır. Ekim ișlemi sonrası homojen çimlenme-çıkıș sağlamak amacıyla tavalara çim suyu verilmiș, daha sonra sulama yapılmamıștır. Yabancı otlar elle kontrol edilmiștir. Tam olgunluk döneminde, her sırada șansa bağlı bașaklı 10 sap üzerinde toprak yüzeyinden en üst bașakçık ucuna kadar olan kısım ölçülerek bitki boyu belirlenmiștir. Bitkiler orakla hasat edilmiș ve parsel biçerdöveri ile harman edilmiș, temizlenen ürün tartılarak tane verimi hesaplanmıștır.

Buğday genotiplerinin çim kını uzunlukları, Atatürk Üniversitesi Ziraat Fakültesi Tarla Bitkileri Bölümü bitki büyütme odalarında, dört farklı test ortamında ve tam șansa bağlı deneme planına göre dört tekrarlı yürütülen araștırmalarda ölçülmüștür.

Toprak-Karanlık Koșullar: Boyutları 80x $100 \times 12 \mathrm{~cm}$ olan ahșap kasaların içi kurutma kâğıdıyla kaplanıp torf ile doldurulmuștur. Her genotipe ait 50 tohum, $2 \mathrm{~cm}$ derinliğinde ve 2 $\mathrm{cm}$ aralıkla ekilip üzerleri kapatımıș, genotipler (sıralar) arasında $5 \mathrm{~cm}$ mesafe bırakılmıștır. Ekim ișlemi sonrası yeterli su verilen kasalar, $15^{\circ} \mathrm{C}$ 'ye ayarlı büyütme odasında karanlık koșullarda 13 gün 8 saat $\left(200^{\circ} \mathrm{C}\right.$ gün toplam sıcaklık akümüle edilinceye kadar) bekletilmiștir. Daha sonra her genotipe ait șansa bağlı 10 bitki özenle sökülmüș, tohum ile ilk yaprağın çıktığı çim kını ucu arasındaki kısım milimetrik cetvelle ölçülmüștür (Rebetzke ve ark. 1999).

Toprak-Aydınlık Koșullar: Bu araștırma, toprak-karanlık koșullardan farklı olarak 16:8 saat aydınlık: karanlık koșullarda yürütülmüștür.

Kâğıt-Karanlık Koșullar: Çapı $15 \mathrm{~cm}$ olan petrilerin içi iki kat kurutma kâğıdı ile kaplandıktan sonra her genotipe ait 50 tohum eșit aralıklarla yerleștirilmiștir. Bu ișlem sonrası yeterli su verilen petriler, $15^{\circ} C^{\prime}$ ye ayarlı büyütme odasına yerleștirilmiș ve karanlık koșullarda 13 gün 8 saat bekletilmiștir. Her genotipe ait șansa bağı 10 bitkinin, tohum ile ilk yaprağın çıktığı çim kını ucu arasındaki kısım milimetrik cetvelle ölçülmüștür.

Kâğıt-Aydınlık Koșullar: Bu araștırma, kağıt-karanlık koșullardan farklı olarak 16 :8 saat aydınlık: karanlık koșullarda yürütülmüștür.
Tescil yilı ile incelenen karakterler arasındaki ilișkiler basit korelasyon analizi (r) ile belirlenmiștir. Biplot analizleri ise GenStat $14^{\text {th }}$ paket programı kullanılarak yapılmıștır.

\section{Bulgular ve Tartıșma}

Genotiplerin bitki boyu, ürün yıllarının ortalamasına göre $80.7-135.8 \mathrm{~cm}$ arasında değișim göstermiștir. En kısa bitki boyuna Seri 82 çeșidi sahip olmuș, bu çeșidi Doğankent-1 ve Orso çeșitleri izlemiștir. En uzun bitki boyu Kıraç 66 çeșidinde ölçülmüș, bu çeșidi Sert Buğday ve Koca Buğday genotipleri izlemiștir. Tescil yllına göre olușturulan genotip gruplarında en kısa bitki boyu $108.1 \mathrm{~cm}$ ile IV. grupta (1988-1994), en uzun bitki boyu ise $125.7 \mathrm{~cm}$ ile I. grupta (yerel genotipler) ölçülmüștür (Çizelge 1). Bitki boyu genetik yapı, ekim sıklığı, ekim zamanı, gübreleme, yağıș durumu ve toprak özelliklerine göre farklılık gösterebilir (Siddique ve ark. 1989). Tosun (1987), kaliteli ve tane verimi yüksek buğday çeșitlerinde bitki boyunun ortalama 80-90 $\mathrm{cm}$ olduğunu bildirmiștir. Brancourt-Hulmel ve ark. (2003), bitki boyu kısalan modern çeșitlerin azotu eski çeșitlere göre daha etkin kullandığını, buna bağlı olarak verimlerin daha yüksek ve kararlı olduğunu bildirmișlerdir.

Genotiplerin tane verimine ilișkin ayrıntılı değerlendirmeler Aydın ve ark. (2011) ve Bayram ve ark. (2017) tarafından daha önce sunulmuștur. Ürün yılları ortalamasına göre genotiplerin tane verimleri 213.5-756.8 $\mathrm{g} / \mathrm{m}^{2}$ arasında değișmiș, en yüksek tane verimi Demir 2000, en düșük tane verimi ise Kılçıksız Buğday genotipinden elde edilmiștir. Genotip grupları içerisinde en düșük tane verimine $394.8 \mathrm{~g} / \mathrm{m}^{2}$ ile I. grup (yerel genotipler), en yüksek tane verimine ise $606.7 \mathrm{~g} / \mathrm{m}^{2}$ ile VI. grup (2000-2006) sahip olmuștur (Çizelge 1).

Buğday genotiplerinin toprak-karanlık koșullardaki çim kını uzunlukları Ozturk ve ark. (2014) tarafından daha önce değerlendirilmiș, en uzun çim kını 73.5 mm ile Ak Buğday, en kısa çim kını ise $38.5 \mathrm{~mm}$ ile Çetinel 2000 genotipinde ölçülmüștür. Tescil yılına göre olușturulan genotip grupları içerisinde en uzun çim kınına $59.6 \mathrm{~mm}$ ile l. grup (yerel genotipler), en kısa çim kınına $47.3 \mathrm{~mm}$ ile Vl. grup (20002006) sahip olmuștur (Çizelge 1). Toprak- 


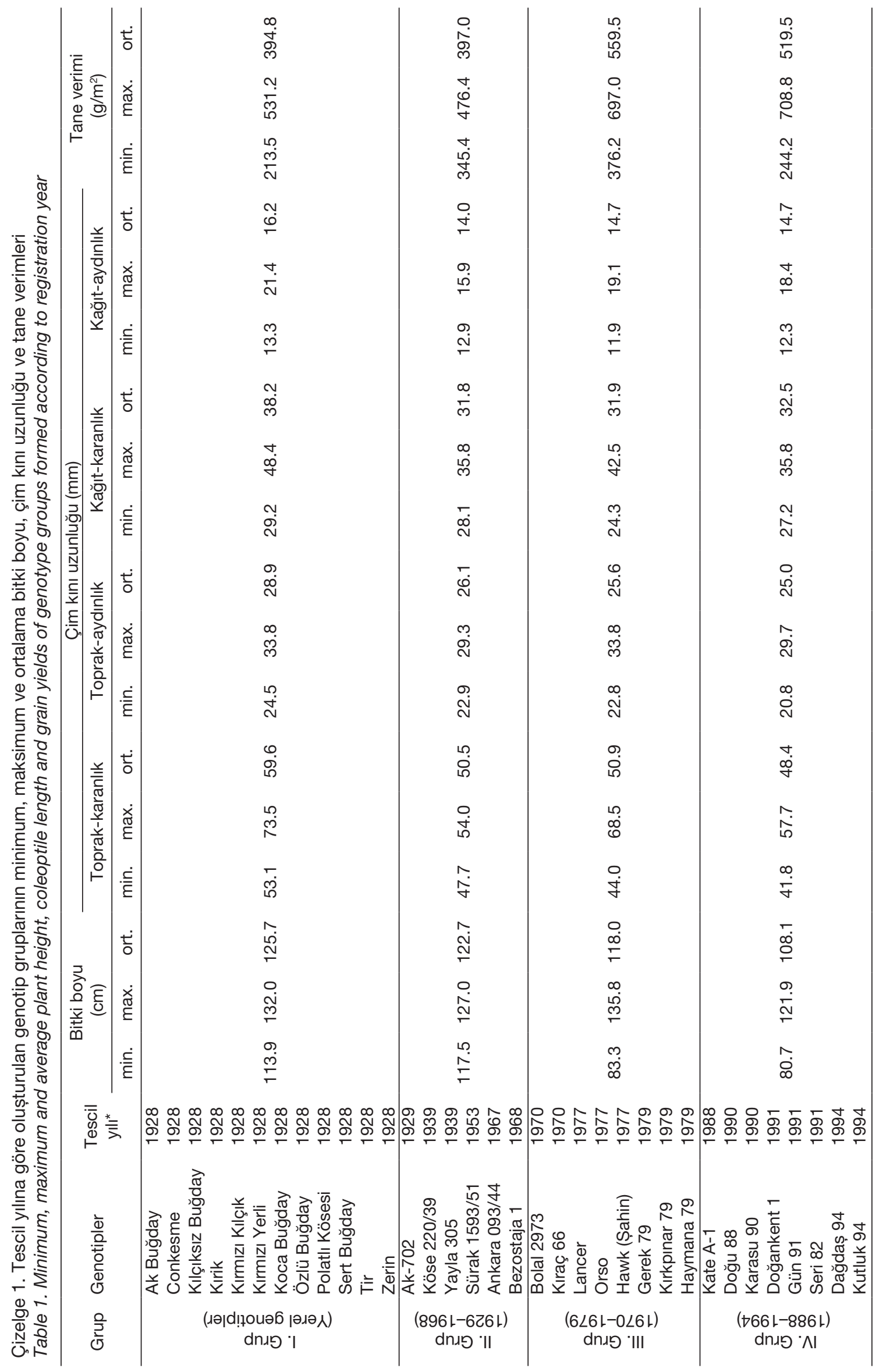




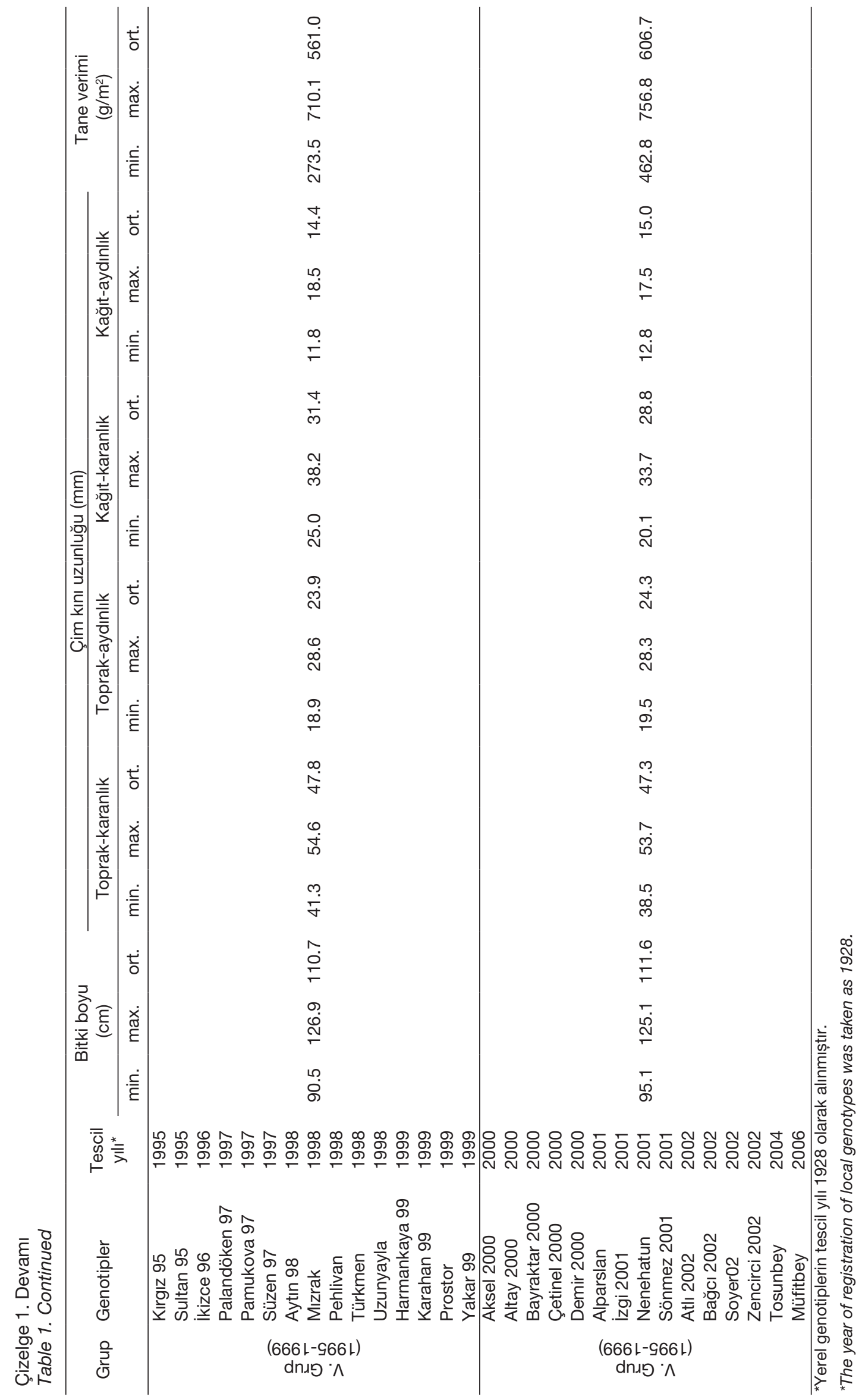


Çizelge 2. Tescil yılı ile bitki boyu, çim kını uzunlukları ve tane verimi arasındaki ilișkiler (r) Table 2. Relationships between plant height, coleoptile length, grain yield with registration year (r)

\begin{tabular}{ll}
\hline Karakterler & Tescil yılı \\
\hline Bitki boyu & $-0.474^{\star \star \star}$ \\
Toprak-karanlık çim kını uzunluğu & $-0.609^{\star \star \star}$ \\
Toprak-aydınlık çim kını uzunluğu & $-0.555^{\star \star \star}$ \\
Kağıt-karanlık çim kını uzunluğu & $-0.480^{\star \star \star}$ \\
Kağıt-aydınlık çim kını uzunluğu & -0.229 \\
Tane verimi & $0.573^{\star \star \star}$ \\
\hline
\end{tabular}

***: 0.001 intimal düzeyinde önemli $(n=64)$.

***: Significant at the probability level of $0.001(n=64)$.

aydınlık koșullarda çim kını uzunlukları 18.9$33.8 \mathrm{~mm}$ arasında değișmiștir. En uzun çim kını Lancer ve Özlü Buğday çeșitlerinde 33.8 mm ölçülmüș, bu çeșitleri Ak Buğday (30.1 $\mathrm{mm})$ ve Kırik $(30.0 \mathrm{~mm})$ genotipleri izlemiștir. En kısa çim kınına ise Uzunyayla, Çetinel 2000 ve İzgi 2001 genotipleri sahip olmuștur. Gruplara göre en uzun çim kınına 28.9 mm ile I. grup (yerel genotipler), en kısa çim kınına ise $23.9 \mathrm{~mm}$ ile V. grubun (1995-1999) sahip olduğu belirlenmiștir (Çizelge 1).

Kâğıt-karanlık koșullarda çim kını uzunlukları 20.1-48.4 mm arasında değișmiș, en uzun çim kını Kılçıksız Buğday, Tir ve Kırik; en kısa çim kını ise Alparslan genotipinde ölçülmüștür. Bu denemede en uzun çim kınına $38.2 \mathrm{~mm}$ ile l. grup (yerel genotipler), en kısa çim kınına ise 28.8 $\mathrm{mm}$ ile VI. grup (2000-2006) sahip olmuștur. Kâğıt-aydınlık koșullarda genotiplerin çim kını uzunlukları 11.8-21.4 mm arasında değișim göstermiș, en uzun çim kını Ak Buğday ve Lancer, en kısa çim kını ise Mızrak ve Orso genotiplerinde ölçülmüștür. Gruplara göre, en uzun çim kınına $16.2 \mathrm{~mm}$ ile I. grup (yerel genotipler), en kısa çim kınına ise $14.0 \mathrm{~mm}$ ile II. grup (1929-1968) sahip olmuștur (Çizelge 1). Araștırma sonuçları, buğday genotiplerinin çim kını uzunluğu yönünden önemli genetik varyasyon gösterdiğine dikkat çeken Rebetzke ve ark. (1999) ve Murphy ve ark. (2008)'in bulguları ile uyumludur. Çim kını uzunluğu, yetișme ve araștırma koșullarına göre de farklılık gösterebilir. Schillinger ve ark. (1998) tarafından 49-119 mm, Murphy ve ark. (2008) tarafından 59-159 mm olarak belirtilen çim kını uzunlukları dikkate alındığında, araștırmada kullanılan buğday genotiplerimizin daha dar bir aralıkta varyasyon gösterdiği söylenebilir. Araștırmada, yerel genotipler ve eski çeșitlerin, modern çeșitlere göre daha uzun çim kınına sahip olduklarına dikkat çekilmiștir.

Genotiplerin tescil yılı ile incelenen karakterler arasındaki ilișkilere ait basit korelasyon katsayılarına göre, tescil yılı ile bitki boyu, toprak-karanlık, toprak-aydınlık ve kâğıt-karanlık çim kını uzunluğu arasındaki ilișkiler olumsuz ve önemli, tescil yılı ile tane verimi arasındaki ilișki ise olumlu ve önemli olmuștur (Çizelge 2). Korelasyon analizi sonuçları, tescil yılı arttıkça bitki boyu ve çim kını uzunluğunun azaldığını, tane veriminin ise arttığını göstermiștir.

Biplot grafiğine göre, toplam varyansın (\%93.85) \%78.81'i birinci temel bileșenle, \%15.05'i ise ikinci temel bileșenle açıklanmıștır. Yerel genotiplerin bitki boyu ve çim kını uzunluklarına çok yakın, tane verimine ise uzak olduğu, tescil yılı arttıkça grupların bitki boyu ve çim kını uzunluğundan uzaklașıp tane verimine yaklaștığı görülmüștür. 2000-2006 döneminde tescil edilen çeșitlerin olușturduğu VI. grubun çim kını uzunluğu ve bitki boyuna en uzak, tane verimine ise en yakın olduğu belirlenmiștir (Șekil 1).

\section{Sonuç}

Araștırma sonuçları, ıslah çalıșmalarının Türk ekmeklik buğday çeșitlerinde bitki boyu ile birlikte çim kınını da kısalttığını, tane verimini ise arttırdığını ortaya koymuștur. Ülkemiz, kuraklığın sürekli bir tehdit unsuru olduğu yarı kurak bir kușakta yer almaktadır. Günümüzde yaygın olarak ekilen yüksek 


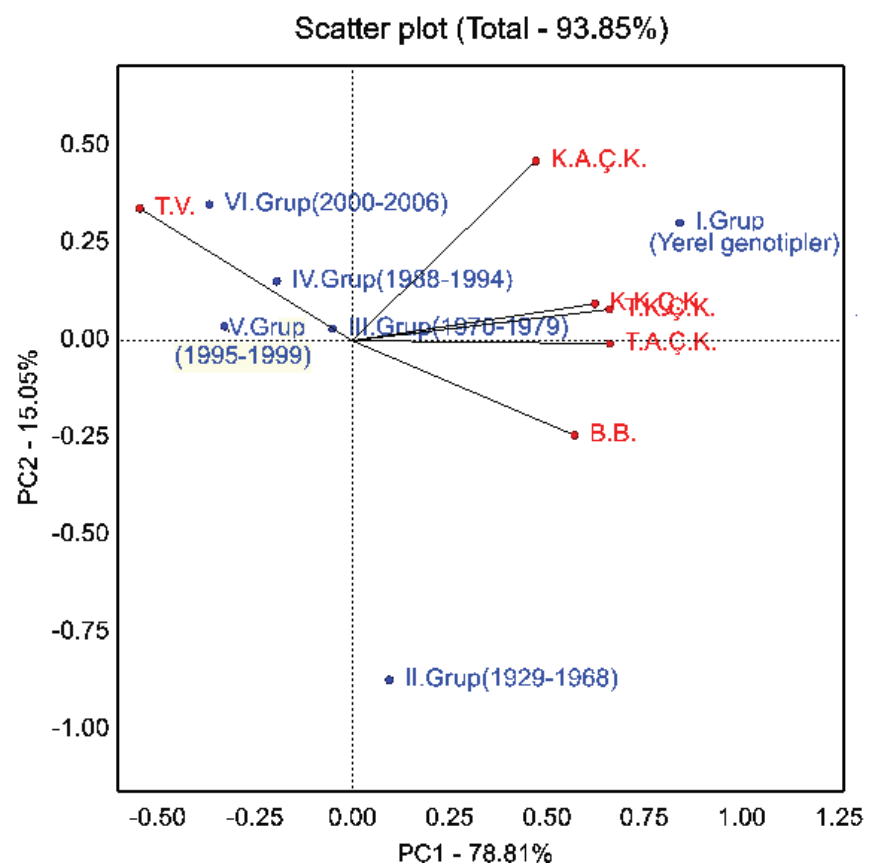

Șekil 1. Tescil yıllarına göre olușturulan grupların incelenen özellikler ile ilișkisi

Figure 1. Relationships with examined features of groups formed according to registration year

verimli modern buğday çeșitlerinin, kısa çim kınları nedeni ile derine ekimin giderek önem kazanacağı ülkemizde, üreticilerin beklentilerini karșılayamama riski vardır. Yüksek verim potansiyeli ile birlikte, bitki boyu kısa fakat çim kını uzun çeșitlerin geliștirilmesi kaçınılmazdır. Islahçıların, yeni çeșitler geliștirirken, bitki boyunun kısalacağı fakat çim kını uzunluğunun bu durumdan etkilenmeyeceği alternatif yöntemler kullanmaları, geliștirilecek çeșitlerin geleceği açısından önemlidir. Çim kını uzunluğu, ekilen tohumların çıkıș oranı ve fide gelișmesini, buna bağlı olarak da verimi etkilemektedir. Serpme ekim yapılan alanlar yanında, nem veya ekim derinliği yönünden elverișsiz tohum yatağı koșullarında, sürgünün toprak yüzeyine çıkıșı ve fide tesisi için çim kını uzunluğu önemli bir etmendir. Uzun çim kınına sahip genotipler, kuru tarım koșullarında daha iyi çıkıș ve fide tesisi olușturarak verim avantajı sağlayabilmektedir. Bu araștırmada, nispeten uzun çim kınına sahip Ak Buğday, Tir, Lancer, Sert Buğday ve Conkesme genotipleri, düșük verim potansiyelleri nedeniyle, erken kuraklığın görüldüğü çevrelerde verim avantajı sağlamaktan uzaktır. Ancak bu genotipler, bitki boyu kısa fakat çim kını daha uzun genotiplerin geliștirilmesine yönelik ıslah programlarında gen kaynağı olarak kullanılabilir.

\section{Teșekkür}

Bu araștırma, Türkiye Bilimsel ve Teknolojik Araștırmalar Kurumu (TÜBITAK) tarafından desteklenen TOVAG 108 O 511 numaralı proje kapsamında yürütülmüștür. Desteklerinden dolayı TÜBITAK'a teșekkür ederiz.

\section{Kaynaklar}

Anonim, 2017. http://www.tuik.gov.tr (Erișim tarihi: 10.07.2017)

Austin R.B., 1998. Yield of wheat in the United Kingdom: recent advances and prospects. Crop Science, 39:1604-1610. doi:10.2135/ cropsci1999.3961604x

Aydın M., Öztürk A., Çağlar O. ve Bayram S., 2011. Ekmeklik buğdayda SPAD değerleri ile verim ve verim unsurları arasındaki ilișkiler. Türkiye IX. Tarla Bitkileri Kongresi. Bildiriler (I): 12-15 Eylül, Bursa, s. 268-271

Bayram S., Öztürk A ve Aydın M., 2017. Ekmeklik buğday genotiplerinin Erzurum koșullarında verim unsurları ve tane verimi yönünden değerlendirilmesi. Yüzüncü Yıl Üniversitesi Tarım Bilimleri Dergisi (Basımda)

Bodega J.L. and Andrade F.H., 1996. The effect of genetic improvement and hybridization on grain and biomass yield of bread wheat. Cereal Research Communications. 24(2):171-177

Brancourt-Hulmel M., Doussinault G., Lecomte C., Berard P., Le Buanec B. and Trottet M., 2003. Genetic improvement of agronomic traits of winter wheat cultivars released in France 
from 1946 to 1992. Crop Science, 43:37-45. doi:10.2135/cropsci2003.3700

Ergene A., 1993. Toprak Biliminin Esasları. Atatürk Üniversitesi Ziraat Fakültesi Yayınları: 267. Ders Kitapları Serisi No: 42, 560 s, Erzurum

Murphy K.M., Dawson J.C. and Jones S.S., 2008. Relationship among phenotypic growth traits, yield and weed suppression in spring wheat landraces and modern cultivars. Field Crops Research, 105:107-115

Ozturk A., Bayram S., Haliloglu K., Aydin M., Caglar O. and Bulut S., 2014. Characterization for drought resistance at early stages of wheat genotypes based on survival, coleoptile length, and seedling vigor. Turkish Journal of Agriculture and Forestry, 38:824-837. doi: 10.3906/tar1402-57

Rebetzke G.J., Richards R.A., Fischer V.M. and Mickelson B.J., 1999. Breeding long coleoptile, reduced height wheats. Euphytica, 106:159-168

Rebetzke G.J., Appels R., Morrison A.D., Richards R.A., McDonald G., Ellis M.H., Spielmeyer W. and Bonnett D.G., 2001. Quantitative trait loci on chromosome $4 \mathrm{~b}$ for coleoptile length and early vigour in wheat (Triticum aestivum L.). Australian Journal of Agricultural Research, 52:1221-1234. doi: 10.1071/AR01042
Rebetzke G.J., Ellis M.H., Bonnett D.G., Mickelson B.J., Condon A.G. and Richards R.A., 2012. Height reduction and agronomic performance for selected gibberellin-responsive dwarfing genes in bread wheat (Triticum aestivum L.). Field Crops Research, 126:87-96

Richards R.A., 1992. The effect of dwarfing genes in spring wheat in dry environments. II. Growth, water use and water use efficiency. Australian Journal of Agricultural Research, 43:529-539

Schillinger W.F., Donaldson E., Allan R.E. and Jones S.S., 1998. Winter wheat seedling emergence from deep sowing depths. Published in Agronomy Journal, 90:582-586

Siddique K.H.M., Perry M.W., Kirby E.J.M, 1989. Ear: Stem Ratio in Old and Modern Wheat Varieties; Relationship with Improvement in Number of Grains Per Ear and Yield. Field Crops Research, 21(1): 59-78

Tang N., Jiang Y., He B. and Hu Y., 2009. The effects of dwarfing genes (Rht-B1b, Rht-D1b, and Rht8) with different sensitivity to GA3 on the coleoptile length and plant height of wheat. Agricultural Sciences in China, 8(9):1028-1038. doi: 10.1016/S1671-2927(08)60310-7

Tosun O., 1987. Türkiye'nin tahıl yetiștirme sorunları ve bunların çözüm yolları. TÜBiTAK Türkiye Tahıl Sempozyumu. Bildiriler: 6-9 Ekim, Bursa, s. 3-7 